\title{
Working
}

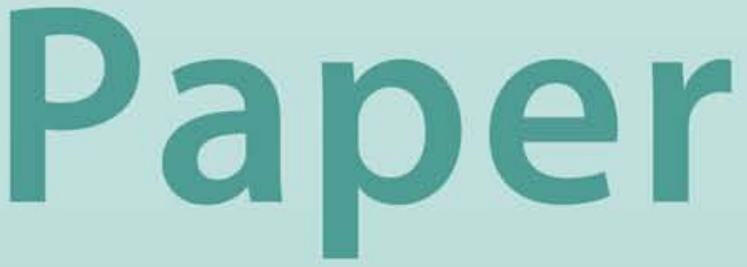


WP/02/49

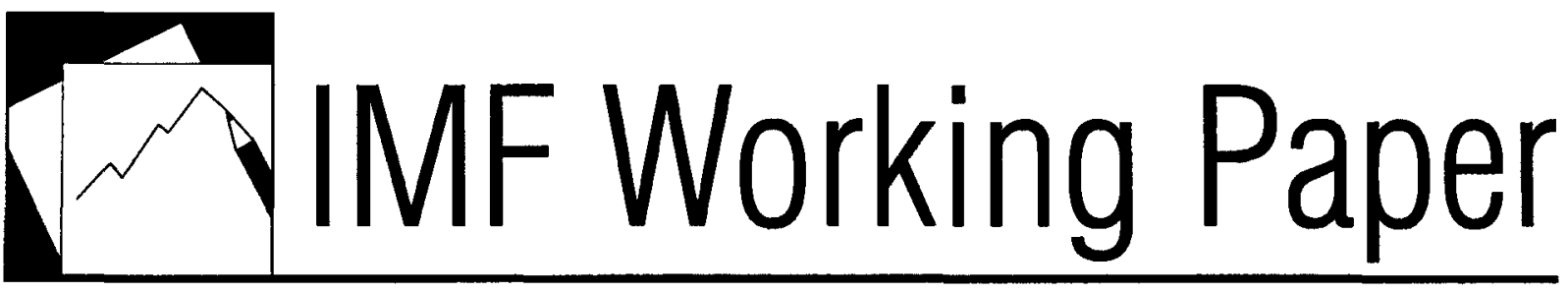

The Rule of Law and the Pattern of Environmental Protection

Per G. Fredriksson and Muthukumara Mani 


\title{
IMF Working Paper
}

\author{
Fiscal Affairs Department
}

\section{The Rule of Law and the Pattern of Environmental Protection}

\author{
Prepared by Per G. Fredriksson and Muthukumara Mani ${ }^{1}$ \\ Authorized for distribution by Michael Keen
}

March 2002

\begin{abstract}
The views expressed in this Working Paper are those of the author(s) and do not necessarily represent those of the IMF or IMF policy. Working Papers describe research in progress by the author(s) and are published to elicit comments and to further debate.
\end{abstract}

We develop and test a theory of the rule of law and environmental policy formation. In our model an increase in the degree of rule of law has two opposing partial effects on environmental policy: first, a greater share of policy decisions are implemented according to law; second, industry bribery efforts increase because more is at stake. Moreover, we find that an increase in corruptibility of policymakers lowers the stringency of environmental policy. The empirical findings suggest that a greater degree of rule of law raises environmental policy stringency, but the effect is lower where corruptibility is high.

JEL Classification Numbers:Q28, D72, D78, K40

Keywords: Property Rights, Corruption, Rule of Law, and Environmental Policy

Author’s E-Mail Address:pfredrik@mail.smu.edu, mmani@imf.org

\footnotetext{
${ }^{1}$ Department of Economics, Southern Methodist University and Fiscal Affairs Department (Environmental Team), International Monetary Fund respectively. We would like to thank, without implicating, Michael J. Keen, Angeliki Kourelis, and Saji Thomas for their constructive comments.
} 


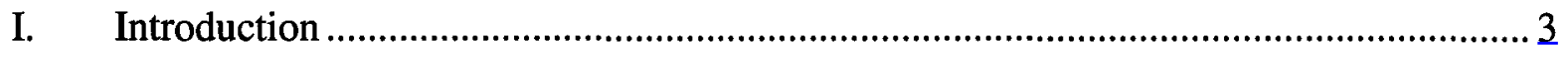

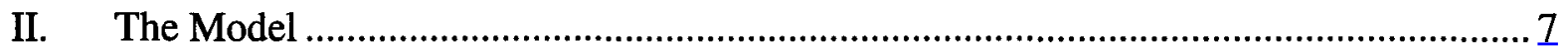

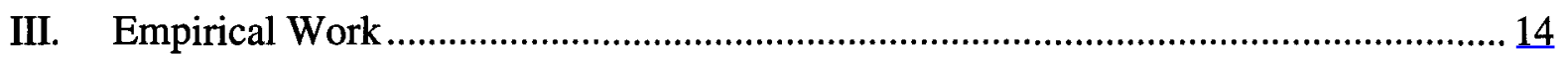

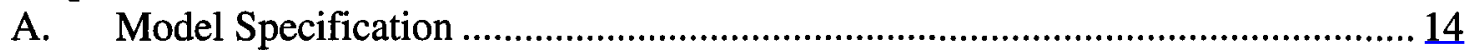

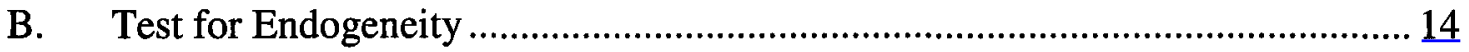

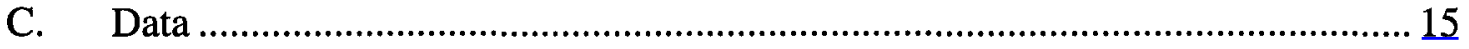

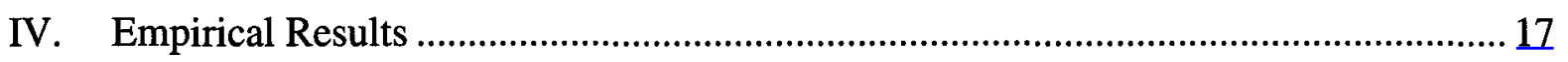

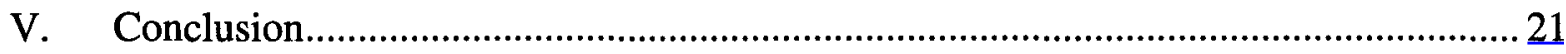

Tables

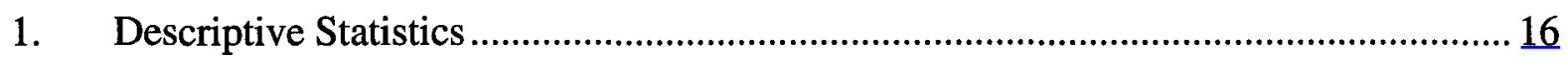

2. Environmental Stringency Equation Regressions, Models 1-8 .............................. 18

3. Environmental Stringency Equation Regressions, Models 9-12 .............................. 20

Figure

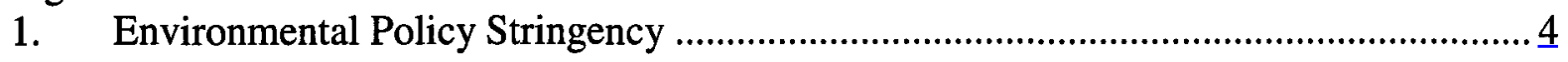

Appendix

1. Variable Definition and Data Sources................................................................. 22

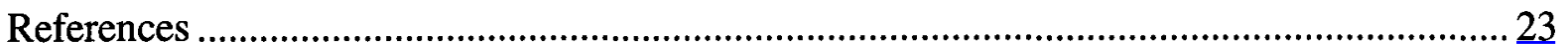




\section{INTRODUCTION}

The existence and enforcement of property rights and the rule of law have been recognized as fundamental for investment and economic growth (Cheung, 1963; Demsetz, 1967; North, 1990; Persson and Tabellini, 1994; Svensson, 1998). ${ }^{2}$ Today, the development of systems securing property rights is being supported by the full range of international and multilateral institutions such as the World Bank and the International Monetary Fund (World Bank, 1994, 1997;

IMF, 1997). Recently, property rights and the degree of ownership risk have been shown to also affect the management of natural resources, especially the rate of deforestation and oil extraction (Deacon, 1994; Bohn and Deacon, 2000). ${ }^{3}$ However, the effects of the rule of law on government policymaking and policy outcomes have, to our knowledge, been neglected. ${ }^{4}$ In this paper, we seek to fill this gap in the literature. ${ }^{5}$

Our focus is on environmental policymaking. We are particularly interested in whether rule of law interacts with corruption in its effect on environmental policy. The stylized facts suggest that this may be the case. Figure 1 shows four different types of countries classified according to their

\footnotetext{
${ }^{2}$ The economic effects of secure property rights and a well-functioning legal system are reasonably straightforward. Since people are, to a considerable degree, self-interested, they tend to undertake hard work and investments only if they have a reasonable probability of enjoying the fruits of their efforts. Thus, if property rights are insecure-for example, because of high crime rates or high rates of taxation or high chances of government expropriation-then people tend to work and invest little. The concept of high taxation can be extended from income taxes or other formal levies to include onerous government regulations and licensing requirements, as well as bribes required by corrupt officials (see Barro, 1997).
}

${ }^{3}$ For instance, in the absence of direct measures the degree of absence of rule of law and property rights, both Deacon (1994) and Bohn and Deacon (2000) study various measures of government instability and absence of government accountability, such as the frequency of revolutions, major constitutional changes, political assassinations, political purges, and the presence of guerrilla warfare. Chichilnisky (1994) and Karp and others (2001) study property rights differences as a source of international trade.

${ }^{4}$ The literature on property rights includes the seminal contribution by Coase (1960) who studies the distribution of property rights. The origins of secure property rights has been discussed for centuries, for example, by Hobbes (1651) and Locke (1690), and more recently by Rawls (1972), Buchanan (1975), Sugden (1986), and Binmore (1994).

\footnotetext{
${ }^{5}$ Rule of law appears important for current policy outcomes. For example, the 1990 s witnessed the importance of the rule of law on the ability of the transition economies to undertake economic reforms. Sachs and Pistor (1997, p. 1) argue that "In 1992, at the initiation of radical market reforms, Russia differed in many ways from the reforming countries of Eastern Europe, and the lack of historical tradition of the rule of law was among the most important of these differences. Nonetheless, few observers guessed how large the lack of sound legal norms and principles, which governed the public and private actions as well as the issues of criminality and state corruption, would loom in the struggle over economic reform."
} 
Figure 1. Environmental Policy Stringency

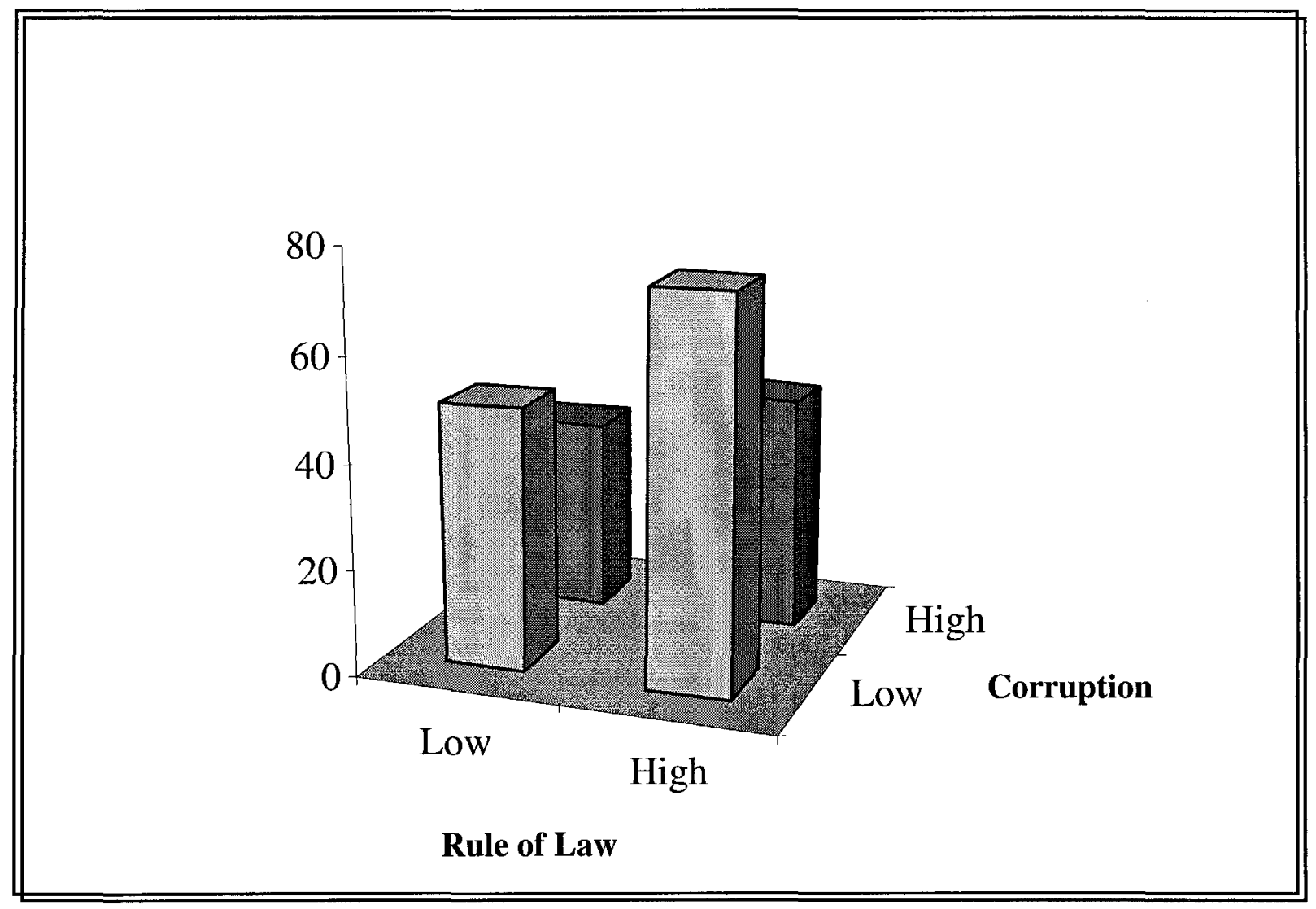

Sources: Environmental stringency data from CIESIN (2001), Corruption data from Transparency International (1999), and rule of law data from Kaufmann and others (1999b). 
levels of rule of law and corruption. ${ }^{6}$ Countries with a low degree of rule of law and high corruption have the lowest stringency of environmental policy. An improvement in the level of rule of law appears to raise environmental policy stringency, but the relative size of such an increase appears greater where the level of corruption is low. On the other hand, Figure 1 suggests that a reduction in corruption has a greater effect where the rule of law is more complete (high). Figure 1 highlights the interdependence between rule of law and corruption, and this paper seeks to shed light on this relationship as it pertains to environmental policymaking.

Environmental policymaking is a suitable policy area to study the effects of the rule of law for several reasons. First, since few pollutants are governed by international agreements, national governments have a high degree of discretion in policymaking. Country specific (political, economic, and environmental) conditions are thus likely to determine environmental protection in most countries in contrast to, for example, trade policy, which to a large degree is determined by multilateral agreements. Second, environmental policy is shaped by political forces in a similar fashion as many other policies such as tax policy, and health and safety regulations. Thus, our results are likely to have more general applicability. Third, environmental policy is unlikely to influence the level of rule of law in most countries, particularly in developing countries. Our empirical work employs data primarily from developing countries, and the direction of causality implies that there is a relatively small risk that feedback effects from distorted environmental protection will influence the degree of rule of law. This increases our confidence in the empirical relationships. Finally, indices measuring the degree of rule of law and the level of environmental protection have recently been created for relatively large samples of countries by the World Bank (see Kaufmann, Kray, and Zoido-Lobaton, 1999a, 1999b) and CIESIN and others (2001), respectively, making it feasible to test the implications of the model.

The theory builds on the common agency model by Grossman and Helpman (1994), developed from Bernheim and Whinston (1986). To our knowledge, the effect of the rule of law has not been studied using this model. ${ }^{7}$ The model has a policymaking government and an industry lobby group. Environmental (pollution) tax policy is assumed to be made up by a large number of small policy decisions. The effective environmental tax policy is assumed to be a weighed average of policy decisions determined with and without complete rule of law. In the first stage

\footnotetext{
${ }^{6}$ Figure 1 is constructed by breaking down the sample of 83 countries into four roughly equally large groups: countries with "low" (weak) and "high" (strong) rule of law and countries with "low" and "high" levels of corruption. "Low" rule of law countries are countries that have value for 0 or lower value for rule of law and "high" rule of law countries are countries with positive values. "Low" corruption countries are the ones with a value of 5 or more for CPI and "high" corruption countries are the ones with index values of less than 5. We then look at the mean environmental policy stringency index for the corresponding matrix cells. The data are described in detail in Section III.

${ }^{7}$ The model has previously been extended to environmental policymaking by Aidt (1998), Conconi (2000), Yu (2000), Damania (2001) and Eliste and Fredriksson (2001). See Heyes and Dijkstra (2001) for a useful survey of the literature on the political economy of environmental policy.
} 
of the game, "nature" selects with some (exogenous) probability whether the rule of law will apply to the particular policy decision, where we define complete rule of law as a situation where (i) policymaking cannot be influenced by influence-seeking, and (ii) property rights are completely secure. In case rule of law is complete, the welfare maximizing environmental tax policy is implemented by the government, and environmental policy cannot be influenced by bribes. In this event, the game ends in stage one.

If, on the other hand, nature determines that the rule of law is incomplete, the policy outcome is determined by a bribery game. Thus, in this model a lack of rule of law is a condition for bribery to occur. In the case where the rule of law is incomplete, the game progresses to the second stage, where a polluting industry lobby promises the government a bribe in return for a favorable environmental policy choice. In the third stage, the government selects its optimal environmental policy, and receives the associated bribe. In its decision, the government weighs the bribe versus aggregate social welfare. The (exogenous) weighting factor is here a measure of the corruptibility of the government. Corruptibility is defined as the willingness to cause social welfare losses in exchange for a bribe.

The degree of rule of law has two impacts on policy decisions in the model: (i) in the selection of whether bribery will occur (the rule of law is incomplete, i.e., lawlessness) or not (the rule of law is complete), and (ii) on the size of the costs involved in protection of property rights in the product market. Note that in the product market a lack of rule of law approximates a profits tax for the industry. As it retains a lower share of profits due to lawlessness, its stake in the environmental policy outcome falls (see also Svensson, 1998).

The main insights of the model are the following. First, an increase in the degree of rule of law has two opposing partial effects on environmental tax policy: (i) more policy decisions are implemented according to the law; and (ii) industry bribery efforts increase. The total impact consequently depends on the relative size of these two effects, and is also conditional on corruptibility. The intuition is that the greater the share of policy decisions taken under complete rule of law, the greater the stringency of environmental policy. On the other hand, once the rule of law is incomplete and bribery occurs, the industry group has more at stake the greater the rule of law, because a greater share of profits are kept as a result of lower costs involved with protecting property rights. This induces an increase in lobbying efforts. This indirect effect of rule of law lowers policy stringency. Moreover, the effect of rule of law is conditional on the level of corruptibility. The nature of this interaction depends on whether the first or the second effect of rule of law is more strongly affected by corruptibility. Thus, the interaction is ambiguous.

Second, an increase in the degree of corruptibility lowers the stringency of environmental tax policy. The effect is decreasing, and is conditional on the degree of rule of law. The intuition is that greater corruptibility is equivalent to a lower government weight on social welfare relative to bribes. This affords the bribe giver a greater opportunity to gain policy favors. This is particularly valuable when property rights are enforced, i.e., when the rule of law prevails to a high degree, and the bribe offer rises in such circumstances. However, because a greater rule of 
law also implies that a bribe is given less frequently, the interaction between corruptibility and rule of law is ambiguous.

Our empirical work evaluates the insights of theory using recent cross-country data for 83 countries. First, rule of law has a positive effect on environmental policy stringency, in particular, when corruptibility is low. Second, greater corruptibility lowers the environmental policy stringency, and the effect is decreasing. Third, the effect of corruptibility is stronger where the level of rule of law is high. The theory explains this finding as a briber-effect: the incentive to offer a bribe rises as the property rights over firm profits improve. Our findings imply that reform of the legal systems may have important effects on environmental policy outcomes. However, bribery may also increase as the rule of law becomes more complete, and reform work need to take this effect into account. We also believe our findings may be applicable to other policy areas.

The paper is organized as follows. Section II sets up the theoretical model and discusses the effects of the rule of law and corruptibility. Section III presents our empirical model and describes the data. Section IV reports the empirical results. Section V offers a brief conclusion.

\section{THE MOdEL}

A small open economy has a "clean" sector which produces a numeraire good $z$, and a polluting import-competing sector, which produces a good $x$. The economy is populated by two types of individuals $k$, consumers (denoted by $S$ ) and factor owners $(F)$. The two population groups are of size $s$ and $f$, respectively, and the population size is normalized to 1 . We assume for simplicity that the factor owners are a highly concentrated group with low membership such that their share of the population is approximately zero, i.e., $f=0$ and $s=1$ (this assumption does not alter our results). All individuals have labor income, factor owners in addition have factor income from ownership of a sector-specific factor. The consumers derive disutility from the pollution associated with local production. An individual $k, k=S, F$, has a utility ${ }^{8}$

$$
U^{k}=c^{z k}+u^{k}\left(c^{x k}\right)-\delta^{s} \theta X
$$

where $c^{z k}$ and $c^{x k}$ are consumption of the numeraire good $z$ and good $x$ by a type $k$, with world and domestic prices equal to 1 and $p^{*}$, respectively. The world market price $p^{*}$ is exogenously given as the small country is a price taker, $u\left(c^{x k}\right)$ is a strictly concave and differentiable subutility function. The indicator variable $\delta^{s}$ takes a value of one if the individual is a consumer, and zero otherwise. This assumption simplifies the analysis, but does not qualitatively change our results. Production of $x$ is given by $X$, and $\theta$ is the per-unit damage coefficient, assumed constant for simplicity. An individual $k$ spending $Y^{k}$ consumes $c^{x}=d\left(p^{*}\right)=u_{\mathrm{c}}{ }^{-1}$ of good $x$ and

\footnotetext{
${ }^{8}$ Quasi-linear preferences may result in corner solutions. However, we assume interior solutions.
} 
$c^{z k}=Y^{k}-p^{*} d\left(p^{*}\right)$ of good $z$. Thus, the indirect utility function of a consumer is expressed as $V^{S}\left(p^{*}, t, Y^{S}\right)=Y^{S}+C\left(p^{*}\right)-\theta X$, where $C\left(p^{*}\right)=u\left[d\left(p^{*}\right)\right]-p^{*} d\left(p^{*}\right)$ is the aggregate consumer surplus derived from consumption of good $x$. There is no consumer surplus from consumption of good $z$.

The government regulates pollution by levying an environmental tax $t \in T, T \in \mathfrak{R}$, on each unit of damage from polluting production activities. Each individual has one unit of labor and the total labor endowment equals $l$. Good $z$ is produced by labor alone with a constant returns to scale technology, and an input-output coefficient equal to one. The labor supply is sufficiently large for the supply of this good to be positive which implies a wage rate equal to one. The inputs into production of good $x$ are labor and a sector-specific factor. The technology is constant returns to scale. Disregarding labor costs, producers of good $x$ face a net price given by $p=p^{*}-t \theta$, and the factor reward depends on the producer's net price $p$, i.e., $\pi(p)$. The supply curve for good $x$ is given by Hotelling's Lemma, i.e., $X(p)=\pi_{p}(p)$, where $X_{p}>0$, and $X_{p p}=0$. Aggregate environmental tax revenues are given by

$$
R(t)=t \theta X(p)
$$

The Rule of Law. In order to model the lack of rule of law (imperfectly enforced property rights), we must first identify the areas where a lack of rule of law has an effect. We focus on two areas. For simplicity, we assume that the same degree (or probability) of lawlessness (absence of a rule of law), applies to both areas. The probability $0 \leq \mu \leq 1$ reflects the likelihood that the rule of law applies, and the probability $0 \leq(1-\mu) \leq 1$ reflects a state of "lawlessness," i.e., the existing law is not followed.

First, in the political market, the existing law is assumed implemented with probability $\mu$, and with probability $1-\mu$ a state of lawlessness occurs. Only in the latter case can the government be bribed to set a more favorable environmental policy.

Second, in the goods market the lack of rule of law implies that factor owners are forced to defend their property and profits. The wasted resources work roughly as a profits tax (see Svensson, 1998). These are the extra costs of doing business due to additional protection measures, nonenforcement by courts of sales contracts (e.g., nonpayment of delivery of goods), etc. We assume that with probability $1-\mu$ the firm makes zero profit due to this extra cost, and thus the expected value of the aggregate factor reward benefiting the factor owners equals $\pi(p) \mu$. In sum, $1-\mu$ reflects the effect of lawlessness in the goods market.

The income obtained by the owners of the sector-specific factor depends on the environmental and trade policies, but only environmental policy can be affected by bribery. Factor owners are assumed able to organize into a lobby group that coordinates a prospective bribe offer to the incumbent government that relates the size of the bribe to the favor given (see, e.g., Damania and Fredriksson, 2000). The consumers are assumed to face severe free-riding problems and are unable to organize politically (see Olson, 1965). 
The Game. We assume that a large number small environmental policy decisions are made by the government. Each decision is taken in isolation from each other. The timing assumptions are as follows:

Stage 1. In the first stage, "nature" announces whether a state of rule of law occurs (with a probability $\mu$ ), or whether a state of lawlessness occurs (with a probability 1- $\mu$ ). In case lawlessness occurs, a three-stage game is played between the government and the lobby. In case the rule of law occurs, the welfare maximizing policy $\tilde{t}$ is selected and implemented and the game stops.

Stage 2. When lawlessness occurs, the lobby group offers the incumbent government a bribe schedule $\Lambda^{F}(\hat{t})$. The lobby offers a specific bribe for each policy choice $\hat{t}$, given the government's anticipated decision rule.

Stage 3. In the case of lawlessness, the incumbent government sets its optimal environmental policy, given the lobby group's strategy. The government collects the associated bribe from the producer lobby. ${ }^{9}$ Moreover, with probability $1-\mu$ the factor owners face a zero factor reward due to imperfectly enforced property rights. The probability that the latter event occurs is not conditional on which state emerges in the political market (in stage 1). The politicians in government use the bribe for their personal consumption. When deciding on the environmental policy, the government weighs the bribe versus aggregate social welfare. The relative weight on social welfare reflects the government's corruptibility in its policy decision. It may be restricted in its willingness to accept bribe offers due to considerations of its reputation or legal reasons. The number (share) of decisions taken which are influenced by bribe offers is reflected by the degree of lawlessness, $1-\mu$.

The effective policy resulting from this game is an environmental tax policy, $t^{\circ}$, which is assumed to be a weighted average of the large number of environmental policy decision determined by the political system (i) under the rule of law, $\tilde{t}$, and (ii) without the rule of law (lawlessness), $\hat{t}$, respectively:

$$
t^{o} \equiv \tilde{t} \mu+\hat{t}(1-\mu)
$$

This assumption builds on the idea that overall government environmental policy consists of a large number of relatively small decisions, where the rule of law applies in some share of these decisions but not in all.

Incomplete Rule of Law. We now determine the environmental tax that emerges from the bribery game, $\hat{t}$, when a state of lawlessness occurs. This environmental tax materializes with

\footnotetext{
${ }^{9}$ Neither the lobby group nor the government is assumed to renege on their promises.
} 
probability $(1-\mu)$. The gross (indirect) utility of the lobby group is given by the expected value of factor income,

$$
E\left[\Omega^{F}(\hat{t}, \tau)\right] \equiv \pi(\hat{p}) \mu
$$

where $E[$.$] is the expectations operator, and \pi(\hat{p}) \mu$ is factor income when the existing laws are not followed (bribery takes place), where $\hat{p}=p^{*}-\hat{t} \theta$. Expression (4) reflects the fact that no matter which tax is set ( $\tilde{t}$ or $\hat{t}$ ), the producers only receive a share $\mu$ of profits due to imperfectly enforced property rights in the goods market. Since we assume a highly concentrated ownership of the specific factor, such that $f=0$, the lobby ignores tax revenues, as well as consumer surplus (it receives a negligible share).

The government values the bribe and aggregate social welfare. Whereas the bribe is used for personal consumption, social welfare is of importance because the incumbent ruler is more likely to win future reelection (or stay in power) the greater is average welfare. The degree of corruptibility is thus bounded by concerns for the government's reputation and by its legal considerations ( e.g., avoidance of impeachment). We assume for simplicity that neither the bribe giver nor the bribe recipient can be punished. In the case of lawlessness, expected aggregate social welfare is given by

$$
E\left[\Omega^{A}(\hat{t})\right] \equiv \pi(\hat{p}) \mu+l+C\left(p^{*}\right)+R(\hat{t})-s \theta X(\hat{p})
$$

which expresses the expected value of the sum of all individuals' aggregate factor rewards, labor income, consumer surplus, tax revenues, and take the consumers' aggregate disutility from pollution.

The incumbent government thus has an objective function equal to

$$
E[G(\hat{t})] \equiv \Lambda^{F}(\hat{t})+a \Omega^{A}(\hat{t}),
$$

which is a weighed sum of the bribe and expected aggregate social welfare. The exogenous parameter $a \geq 0$ is the weight on welfare relative to bribes and revenues. In our view, this weight reflects the degree of corruptibility of the government, i.e., the willingness to accept the bribe in return for setting less stringent policy. Note that in the present model the bribe aims to influence government policy and not elections (Schulze and Ursprung, 2001; see also López and Mitra, 2000). Our perspective is similar to Bardhan's (1997, p. 1321) view of corruption who argues that "the use of public office for private gain" (p. 1321), and Shleifer and Vishny's (1993, p. 599) who define government corruption as "the sale by government officials of government property for personal gain." 
The Nash equilibrium in the bribery game is found using two necessary conditions (as in the well-known model by Grossman and Helpman, 1994):

$$
\begin{aligned}
& \hat{t}^{*}=\underset{\hat{t}}{\arg \max } \Lambda^{F^{*}}(\hat{t})+a \Omega^{A}(\hat{t}) \text { on } \mathrm{T} ; \\
& \hat{t}^{*}=\underset{\hat{t}}{\arg \max }\left[\Omega^{F}(\hat{t})-\Lambda^{F^{*}}(\hat{t})\right]+\left[\Lambda^{F^{*}}(\hat{t})+a \Omega^{A}(\hat{t})\right] \text { on } \mathrm{T} .
\end{aligned}
$$

In the bribery game, the equilibrium policy $\hat{t}^{*}$ simultaneously maximizes the government's utility function [condition (K1)] and the joint utility of the lobby and the incumbent [condition (K2)], given the degree of rule of law. The equilibrium characterization is found by taking the first-order conditions of (K1) and (K2), which yields

$$
\Lambda_{\hat{\imath}}^{F^{*}}\left(\hat{t}^{*}\right)+a \Omega_{\hat{t}}^{A}\left(\hat{t}^{*}\right)=0
$$

and

$$
\left[\Omega_{\hat{t}}^{F}\left(\hat{t}^{*}\right)-\Lambda_{\hat{t}}^{F^{*}}\left(\hat{t}^{*}\right)\right]+\Lambda_{\hat{t}}^{F^{*}}\left(\hat{t}^{*}\right)+a \Omega_{\hat{t}}^{A}\left(\hat{t}^{*}\right)=0 .
$$

Substituting (6) into (7) yields $\Omega_{\hat{t}}^{F}\left(\hat{t}^{*}\right)=\Lambda_{\hat{i}}^{F}\left(\hat{t}^{*}\right)$, which reflects the local truthfulness of the bribe schedule (see Grossman and Helpman, 1994). The equilibrium characterization of the environmental tax is found by substituting the truthfulness condition into (7), which yields

$$
\Omega_{\hat{t}}^{F^{*}}\left(\hat{t}^{*}\right)+a \Omega_{\hat{t}}^{A}\left(\hat{t}^{*}\right)=0 .
$$

Differentiating Equations (4), (5), and (6) with respect to the environmental tax $\hat{t}$ yields

$$
\Omega_{\hat{t}}^{F}(\hat{t})=-\theta X \mu,
$$

and

$$
\Omega_{\hat{f}}^{A}(\hat{t})=-\theta X \mu+\theta X-\hat{t} \theta^{2} X_{p}+s \theta^{2} X_{p}
$$

Substituting expressions (10) and (11) into Equation (9) and simplifying we find the following equilibrium characterization of the environmental policy in the bribery game equilibrium:

$$
-(1+a) X \mu+a\left(X+(s-\hat{t}) \theta X_{\hat{p}}\right)=0 .
$$

Equation (12) implicitly defines the equilibrium environmental tax policy, $\hat{t}^{*}$. In order for (12) to represent a maximum, the SOC is required to be negative. The SOC equals $\theta X_{\hat{p}}[(1+a) \theta \mu-2 \mathrm{a}]$, 
which is negative under the condition that $\mu<2 a /[(1+a) \theta]$. We assume this to be the case (see Assumption 1 below).

The welfare maximizing equilibrium. Ignoring the lack of rule of law, i.e., setting $\mu=1$, implies that social welfare is expressed as

$$
\Omega^{A}(\tilde{t}) \equiv \pi(\tilde{p})+l+C\left(p^{*}\right)+R(\tilde{t})-s \theta X(\tilde{p})
$$

The welfare maximizing environmental tax is found by taking the FOC of $\left(5^{\prime}\right)$, which yields $\tilde{t}=s=1$, equal to the marginal disutility from pollution, $s$.

The rule of law, corruptibility, and policy. In this section we analyze the effects of the degree of rule of law on environmental protection outcomes, accounting for the level of corruptibility. The aim is to derive testable hypotheses for our empirical work carried out in later sections.

In order to discuss the effect of rule of law on the effective environmental tax, we differentiate Equation (3), which yields

$$
\frac{d t^{o}}{d \mu}=\underbrace{\tilde{t}-\hat{t}}_{A}+\underbrace{(1-\mu) \frac{\partial \hat{t}}{\partial \mu}}_{B} .
$$

In order to sign expression (13), we sign the partial effects $(\tilde{t}-\hat{t})$ (effect $A$ ) and $\partial \hat{t} / \partial \mu$ (effect $B$ ). Rearranging Equation (12) and solving for $\hat{t}$ yields a bribery equilibrium environmental tax equal to

$$
\hat{t}=s+\frac{X}{\theta X_{p}}-\frac{(1+a) X \mu}{a X_{p}} .
$$

To simplify the discussion below, we assume that the welfare maximizing tax rate, $\tilde{t}$, is greater than the tax rate set when the rule of law does not apply, $\hat{t}$. Since $\tilde{t}=s$, this assumption requires that $\mu>a /[(1+a) \theta]$ such that the sum of the second and third terms in (14) is negative. We sum our two assumptions on the parameter values in the following way:

Assumption 1: $\frac{a}{(1+a) \theta}<\mu<\frac{2 a}{(1+a) \theta}$.

Assumption 1 ensures that the government's maximization problem has a unique maximum, and that the environmental policy set in the absence of rule of law is less stringent than the welfare maximizing policy. 
To determine the sign of effect $B$ in (13), we differentiate Equation (12), which yields

$$
\frac{\partial \hat{t}}{\partial \mu}=\frac{(1+a) X}{\theta X_{\hat{p}}[(1+a) \theta \mu-2 a]},
$$

where the denominator is negative under Assumption 1. An increase in the degree of rule of law reduces $\hat{t}$ because the share of profits retained by the firms increases, raising the lobby's incentive to offer a bribe. Moreover, it also raises the implicit weight on firm profits in the government's expression for social welfare. These two effects cause the environmental tax to decline.

The aggregate effect of rule of law on the environmental tax is found by substituting (15) into (13), which yields

$$
\frac{d t^{o}}{d \mu}=\underbrace{\tilde{t}-\hat{t}}_{A}+\underbrace{(1-\mu) \frac{(1+a) X}{\theta X_{\hat{p}}[(1+a) \theta \mu-2 a]}}_{B} .
$$

There are two opposing effects of an increase in the degree of rule of law. Effect $A$ in (13') represents an increase in the tax rate due to an increase in the share of policy decisions where the welfare maximizing policy is implemented. Effect $B$ is the reduction in the tax rate shown in (15), but adjusted by the share of decisions where rule of law is not in force. In the case where effect $(A) B$ dominates the aggregate effect of an increase in the degree of rule of law is positive (negative). We can determine the sign of (13') only for $\mu=1$. In this case, a decrease in $\mu$ unambiguously reduces $t^{o}$ under Assumption 1.

Moreover, the impact of rule of law is nonlinear, as seen from the second derivative

$$
\frac{\partial^{2} t^{o}}{\partial \mu^{2}}=\frac{2(1+a) X}{\theta X_{p}[(1+a) \theta \mu-2 a]}-\frac{(1-\mu)(1+a)^{2} X}{X_{p}[(1+a) \theta \mu-2 a]^{2}},
$$

which is negative under Assumption 1. Finally, further differentiation also reveals that the sign of $\partial^{2} t^{o} / \partial \mu \partial a$ is ambiguous, but different from zero, i.e., the impact of rule of law is conditional on the level of corruptibility. The ambiguity arises because corruptibility, $a$, influences effects $A$ and $B$ in (13') in several opposing ways.

The total impact of corruptibility on the environmental tax is given by differentiation of (3), using (12), which yields

$$
\frac{d t^{o}}{d a}=(1-\mu) \frac{X(\mu-1)+(\hat{t}-s) \theta X_{\hat{p}}}{\theta X_{\hat{p}}[(1+a) \theta \mu-2 a]}
$$


which is positive. Greater corruptibility lowers the environmental tax. Corruptibility only affects the effective tax to the extent that environmental policy decisions are taken without following the rule of law. Further differentiation of (17) reveals that the effect of corruptibility is decreasing since

$$
\frac{\partial^{2} t^{o}}{\partial a^{2}}=-(1-\mu) \frac{(\theta \mu-2)\left(X(\mu-1)-(s-\hat{t}) \theta X_{\hat{p}}\right)}{\theta X_{\hat{p}}[(1+a) \theta \mu-2 a]^{2}}
$$

is negative. Finally, the effect of corruptibility can be shown to be conditional on the degree of rule of law since $\partial^{2} t^{o} / \partial a \partial \mu \neq 0$, but ambiguous. The ambiguity is due to the fact that when property rights are enforced (greater rule of law), each bribe offer rises; but a greater rule of law also implies that bribes are given less frequently.

The ambiguities that emerge afford the empirical work below the opportunity to determine the correct sign and shape of the relationship between rule of law, corruption, and environmental policy stringency.

\section{EMPIRICAL WORK}

\section{A. Model Specification}

Although stylized, the theoretical model developed in the previous section yields testable implications of the relationships between rule of law, corruptibility, and environmental policy formation. First, rule of law has two opposing effects, and thus the net impact depends on the relative size of these two forces. The effect is conditional on corruptibility, although the exact sign of this interaction is indeterminate. Second, corruptibility reduces environmental policy stringency and the effect is decreasing. The effect of corruptibility is conditional on the degree of rule of law, but this interaction effect is indeterminate. We test these implications using cross-country data on environmental policy.

The base-case empirical estimation can be formulated as follows:

$$
S T R_{i}=x_{i}^{\prime} \beta^{x}+\beta^{R U L E} R U L E_{i}+\beta^{C O R} C O R_{i}+\beta^{R U L E^{*} C O R} R U L E_{i}^{*} C O R_{i}+\varepsilon_{i},
$$

where $S T R_{i}$ is the stringency of environmental policy in country $i, x_{i}$ is a vector of controls, $R U L E_{i}$ is a measure of the prevailing rule of law, $C O R_{i}$ is corruption, and $\varepsilon_{i}$ is a zero mean error term. Whereas $\beta^{R U L E}, \beta^{C O R}$, and $\beta^{R U L E^{*} C O R}$ are coefficient scalars, $\beta^{x}$ is a coefficient vector. Several extensions of this empirical model will include higher-order terms.

\section{B. Test for Endogeneity}

Given the potential endogeneity of the rule of law and corruption variables, we test for the necessity of an instrumental variable approach, i.e., whether the set of estimates obtained by OLS 
are consistent or not. We use the augmented regression test (DWH test) developed by Davidson and MacKinnon (1993). The test is performed by including the residuals of each endogenous right-hand side variable as a function of all exogenous variables in a regression of the original model. ${ }^{10}$ Smaller p-values for corruption (0.0041) and rule of law (0.0032) indicate that OLS is inconsistent. We correct for the endogeneity of these two variables by using Two-Stage Least Squares (2SLS). We also test for possible heteroskedasticity and correct this using the standard White's correction. ${ }^{11}$

\section{Data}

We now describe the variables used in the empirical work. The descriptive statistics is summarized in Table 1, and the data appendix contains a further description of the data and sources. The measure of the stringency of environmental policy is an index developed as a sub-index of the recent 2001 Environmental Sustainability Index (ESI) developed by CIESIN and others (2001). The ESI is based on 22 core indicators, each of which combines 2-6 variables. We employ the sub-index Environmental Stringency, which captures the extent to which a country has in place institutions and policies that result in effective responses to environmental problems (i.e., laws on the book, implementation, monitoring, and enforcement).

Environmental Stringency ranges from 0-100, where a higher value implies greater environmental policy stringency.

A measure of Rule of Law has recently been developed by Kaufmann and others (1999b) for the years 1997-98. Rule of Law is a composite index that includes several indicators measuring the extent to which agents have confidence in and abide by the rules of society. These include perceptions of the incidence of both violent and nonviolent crime, effectiveness and predictability of the judiciary, and the enforceability of contracts. Together, these indicators measure the degree to which a society has fair and predictable rules and laws as a basis for economic and social interactions. Thus, Rule of Law should also reflect the degree to which property rights are fully secure.

We use the Corruption Perceptions Index developed by Transparency International as a proxy for "corruptibility." It measures the "perceptions of the degree of corruption as seen by business people, risk analysts, and the general public." The index is computed as the simple average of a number of different surveys assessing each country's level of corruption. We call the variable Corruption and it ranges between 0 (perfectly clean) and 10 (highly corrupt). ${ }^{12}$ In our

\footnotetext{
${ }^{10}$ This is an augmented form of the Hausman test for contemporaneous correlation between the error term and the regressors, used to test exogeneity of variables (Hausman,1983). The low p-values indicate that OLS is inconsistent.

${ }^{11}$ White's general test statistic for our model was statistically significant at 48.712 with a p-value of 0.2211 suggesting presence of heteroskedasticity.

12 The index is inverted in the scale from the original data by subtracting values from 10 to make results more intuitive. A number of recent empirical studies of corruption have employed this index, including Treisman (2000).
} 
Table 1. Descriptive Statistics

\begin{tabular}{lccccc}
\hline Variable & $\begin{array}{c}\text { Number of } \\
\text { Observations }\end{array}$ & Mean & $\begin{array}{c}\text { Standard } \\
\text { Deviation }\end{array}$ & Minimum & Maximum \\
\hline Environmental stringency & 118 & 46.9 & 18.4 & 18.1 & 92.3 \\
GDP & 159 & 7000 & 7427 & 458 & 33505 \\
Openness & 152 & 2.7 & 1.2 & 1.0 & 5.0 \\
Corruption & 83 & 5.3 & 2.3 & 0.0 & 8.3 \\
Control of corruption & 155 & 0.0 & 0.9 & -1.6 & 2.1 \\
Rule of law & 166 & 0.0 & 0.9 & -2.2 & 2.2 \\
Percent nonagricultural labor & 170 & 61.9 & 28.1 & 5.9 & 99.6 \\
OECD & 206 & 0.1 & 0.3 & 0.0 & 1.0 \\
Democracy & 95 & 0.2 & 0.4 & 0.0 & 1.0 \\
Civic freedom & 191 & 3.6 & 1.8 & 1.0 & 7.0 \\
Common law & 95 & 0.3 & 0.5 & 0.0 & 1.0 \\
Civil War & 219 & 0.2 & 0.4 & 0.0 & 1.0 \\
\hline
\end{tabular}

robustness check, we use a Control of Corruption index developed by Kaufmann and others. $(1999 a, 1999 b) .^{13}$ It measures perceptions of corruption in a country, and takes values from -2.5 to 2.5 , where a higher value implies less corruption. Complementing our theoretical model in the hypothesis specification, previous empirical studies provide advice regarding control variables (see, e.g., Eliste and Fredriksson, 2001). Two sets of controls seek to capture structural features and demand factors that may influence environmental policy. First, if environmental quality is a normal good income raises the demand for environmental policies (Kahn and Matsusaka, 1997). Moreover, many studies have found a nonlinear (inverted $U$ ) relationship between income and environmental quality, and we thus include purchasing power adjusted per capita GDP and GDP $^{2}$ (see, e.g., Hettige and others 2000).

The degree of trade openness has been shown by, e.g., Antweiler and others. (2001) to influence environmental policy and quality. We use the Openness index developed by the Heritage Foundation and the Wall Street Journal (O'Driscoll and others 2000). An economy is classified as a " 5 " if it has an average tariff rate of $\leq 4$ percent and/or has very few nontariff barriers, and a " 1 " if the average tariff rate is $>19$ percent and/or there are very high nontariff barriers that are prohibitive.

${ }^{13}$ The indicator reflects the perceptions of a large number of survey respondents of the quality of governance in industrial and developing countries during 1997 and 1998 as well as nongovernmental organizations, commercial risk rating agencies, and think tanks. 
Industrial environmental policies are influenced by the political activities of workers employed in polluting sectors. The greater their stake in the policy outcome, the greater their political pressure and success. However, Olson's (1965) seminal theory of free riding implies that political influence may decline as the size of an interest group increases. We use the proportion of the total labor force in nonagricultural sectors (Percent Nonagricultural Labor) as our measure of worker political pressure on industry environmental policies. The labor force here comprises all workers conforming to the International Labor Organization's definition of the economically active population. We have no prior expectations on Percent Nonagricultural Labor. We include a dummy variable for industrial countries (OECD) to control for the overall level environmental policy differences between developed and developing countries. ${ }^{14} \mathrm{We}$ expect OECD to take a positive sign.

We use a number of instrumental variables for Corruption (Control of Corruption) and Rule of Law. We model the determinants of corruption into two main categories, namely standard economic controls, and political and legal history (see, e.g., Fisman and Gatti, 2000). Our political variables include Democracy, Legal Origin (Common Law) (see La Porta and others 1999), and Civic Freedom and a dummy for countries engaged in Civil War as instruments for rule of law (see also Deacon, 1994; Bohn and Deacon, 2000). The test of overidentifying restrictions was applied to the various sets of instruments and it indicates these are valid instruments. ${ }^{15}$ We tested our model empirically using a sample of 83 countries for which data is available on all variables.

\section{EMPIRICAL RESULTS}

The 2SLS regression results for the Environmental Stringency equation are presented in Table 2. In general, the results appear robust under alternate specifications. Models 1 and 2 suggest that an increase in Corruption reduces the stringency of environmental regulation, and that the marginal effect is decreasing as evidenced by the positive and (marginally) significant Corruption". This is consistent with the theory. In Models 3 and 4, we include Rule of Law which enters with significant and positive coefficients suggesting that the direct effect of rule of law outlined by our theory outweighs the indirect effect. However, the significance level of the Corruption coefficients decline, indicating that Rule of Law is relatively important for environmental policy outcomes, even compared to corruption. Models 5 and 6 show that an increase in Rule of Law has a positive net effect on environmental policy stringency. It appears that in Equation (13'), the direct effect $(A)$ dominates the indirect effect $(B)$ of rule of law. With (Rule of Law) ${ }^{2}$ significantly positive the effect in nonlinear as predicted by the theory, but with the wrong sign.

\footnotetext{
${ }^{14}$ We do not include a measure of the marginal damage from pollution since this will be determined by environmental policy.

${ }^{15}$ The order condition necessary for identification is satisfied since both the corruption and the rule of law equations are overidentified.
} 
Table 2. Environmental Stringency Equation Regressions, Models 1-8

(Two-Stage Least Squares)

\begin{tabular}{|c|c|c|c|c|c|c|c|c|}
\hline Variable & Model 1 & Model 2 & Model 3 & Model 4 & Model 5 & Model 6 & Model 7 & Model 8 \\
\hline GDP & $\begin{array}{r}0.0003 \\
(0.3)\end{array}$ & $\begin{array}{r}0.0008 \\
(0.7)\end{array}$ & $\begin{array}{r}-0.003 \\
(1.9)^{* * *}\end{array}$ & $\begin{array}{r}-0.002 \\
(1.7)^{* * *}\end{array}$ & $\begin{array}{r}-0.002 \\
(1.8)^{* * *}\end{array}$ & $\begin{array}{r}-0.002 \\
(1.8)^{* * *}\end{array}$ & $\begin{array}{r}-0.002 \\
(1.7)^{* * *}\end{array}$ & $\begin{array}{r}-0.002 \\
(1.8)^{* * *}\end{array}$ \\
\hline $\mathrm{GDP}^{2}$ & $\begin{array}{r}2.45 \mathrm{e}-08 \\
(0.8)\end{array}$ & $\begin{array}{r}3.61 \mathrm{e}-10 \\
(0.01)\end{array}$ & $\begin{array}{r}8.40 \mathrm{e}-08 \\
(2.5)^{* *}\end{array}$ & $\begin{array}{r}6.69 \mathrm{e}-08 \\
(1.8)^{* *}\end{array}$ & $\begin{array}{r}5.43 \mathrm{e}-08 \\
(2.0)^{* *}\end{array}$ & $\begin{array}{l}5.87 \mathrm{e}-08 \\
(1.8)^{* * *}\end{array}$ & $\begin{array}{l}5.38 \mathrm{e}-08 \\
(1.7)^{* * *}\end{array}$ & $\begin{array}{l}6.01 \mathrm{e}-08 \\
(1.9)^{* * * *}\end{array}$ \\
\hline Corruption $^{+}$ & $\begin{array}{r}-4.63 \\
(3.4)^{*}\end{array}$ & $\begin{array}{r}-9.97 \\
(3.1)^{*}\end{array}$ & $\begin{array}{r}-2.31 \\
(1.7)^{* * *}\end{array}$ & $\begin{array}{r}-5.8 \\
(1.9)^{* * *}\end{array}$ & $\begin{array}{r}-1.74 \\
(1.2)\end{array}$ & $\begin{array}{r}-0.20 \\
(0.1)\end{array}$ & $\begin{array}{r}-1.22 \\
(0.8)\end{array}$ & $\begin{array}{r}-8.71 \\
(1.1)\end{array}$ \\
\hline Corruption $^{2+}$ & & $\begin{array}{r}0.54 \\
(1.7)^{* * *}\end{array}$ & & $\begin{array}{l}0.35 \\
(1.2)\end{array}$ & & $\begin{array}{l}-0.14 \\
(0.4)\end{array}$ & & $\begin{array}{l}-0.87 \\
(1.2)\end{array}$ \\
\hline OECD & $\begin{array}{l}2.28 \\
(0.5)\end{array}$ & $\begin{array}{l}2.29 \\
(0.6)\end{array}$ & $\begin{array}{l}0.17 \\
(0.1)\end{array}$ & $\begin{array}{l}0.23 \\
(0.1)\end{array}$ & $\begin{array}{l}0.83 \\
(0.2)\end{array}$ & $\begin{array}{l}0.87 \\
(0.2)\end{array}$ & $\begin{array}{l}0.37 \\
(0.1)\end{array}$ & $\begin{array}{l}0.47 \\
(0.1)\end{array}$ \\
\hline $\begin{array}{l}\text { Percent } \\
\text { nonagricultural } \\
\text { labor }\end{array}$ & $\begin{array}{r}-0.10 \\
(1.7)^{* * * *}\end{array}$ & $\begin{array}{l}-0.09 \\
(1.4)\end{array}$ & $\begin{array}{r}0.029 \\
(0.3)\end{array}$ & $\begin{array}{l}0.03 \\
(0.4)\end{array}$ & $\begin{array}{r}0.04 \\
(0.5)\end{array}$ & $\begin{array}{l}0.04 \\
(0.5)\end{array}$ & $\begin{array}{l}0.04 \\
(0.5)\end{array}$ & $\begin{array}{l}0.03 \\
(0.4)\end{array}$ \\
\hline Openness & $\begin{array}{r}3.98 \\
(3.7)^{*}\end{array}$ & $\begin{array}{r}4.17 \\
(3.9)^{*}\end{array}$ & $\begin{array}{r}5.12 \\
(4.6)^{*}\end{array}$ & $\begin{array}{r}5.2 \\
(4.7)^{*}\end{array}$ & $\begin{array}{r}5.12 \\
(4.8)^{*}\end{array}$ & $\begin{array}{r}5.08 \\
(4.8)^{*}\end{array}$ & $\begin{array}{r}5.24 \\
(4.8)^{*}\end{array}$ & $\begin{array}{r}5.15 \\
(4.9)^{*}\end{array}$ \\
\hline Rule of law ${ }^{+}$ & & & $\begin{array}{r}20.2 \\
(3.5)^{*}\end{array}$ & $\begin{array}{r}19.7 \\
(3.5)^{*}\end{array}$ & $\begin{array}{r}19.9 \\
(3.6)^{*}\end{array}$ & $\begin{array}{r}19.1 \\
(3.6)^{*}\end{array}$ & $\begin{array}{r}31.3 \\
(3.7)^{*}\end{array}$ & $\begin{array}{r}45.7 \\
(3.1)^{* \prime}\end{array}$ \\
\hline$(\text { Rule of law })^{2+}$ & & & & & $\begin{array}{r}6.51 \\
(2.7)^{* *}\end{array}$ & $\begin{array}{r}7.12 \\
(2.4)^{* *}\end{array}$ & & \\
\hline $\begin{array}{l}\text { Corruption" } \\
\text { Rule of law }\end{array}$ & & & & & & & $\begin{array}{r}-1.96 \\
(2.1)^{* *}\end{array}$ & $\begin{array}{r}-4.28 \\
(2.1)^{* *}\end{array}$ \\
\hline Constant & $\begin{array}{r}64.2 \\
(5.7)^{*}\end{array}$ & $\begin{array}{r}72.4 \\
(6.2)^{*}\end{array}$ & $\begin{array}{r}57.0 \\
(5.6)^{*}\end{array}$ & $\begin{array}{r}62.5 \\
(6.3)^{*}\end{array}$ & $\begin{array}{r}49.8 \\
(4.8)^{*}\end{array}$ & $\begin{array}{r}46.8 \\
(3.6)^{*}\end{array}$ & $\begin{array}{r}46.2 \\
(3.9)^{*}\end{array}$ & $\begin{array}{l}20.0 \\
(0.8)\end{array}$ \\
\hline $\mathrm{R}^{2}$ & 0.835 & 0.839 & 0.872 & 0.873 & 0.881 & 0.881 & 0.877 & 0.879 \\
\hline $\begin{array}{l}\text { Number of } \\
\text { observations }\end{array}$ & 83 & 83 & 83 & 83 & 83 & 83 & 83 & 83 \\
\hline
\end{tabular}

$t$ - statistics in parenthesis

* Statistically significant at 1 percent level

**Statistically significant at 5 percent level

***Statistically significant at 10 percent level

+ predicated (fitted) values 
Our theory suggests that there is an interaction effect between the degree of rule of law and corruptibility, although the direction is ambiguous. In Models 7 and 8 the relevant interaction terms are included. Rule of Law remains positive and significant, and the interaction term Rule of Law*Corruption is negative and significant. This indicates that the effect of rule of law is greater where the level of corruption is low. Overall, however, Rule of Law has a positive effect on Environmental Stringency even in highly corrupt countries. Consider the parameter estimate measured at the sample means in Model 8: $\partial$ Environmental Stringency/ $\partial \mathbf{R u l e}$ of Law $=45.7-$ $4.28(5.3)=23.0$.

Our findings also imply that Corruption has a negative effect on environmental policy stringency, conditional on a high degree of Rule of Law. From Models 7 and 8, it appears that some degree of rule of law is necessary for corruption to have a significant impact. The incentive to bribe policymakers appears greater where property rights are more secure consistent with the theory.

As a robustness check, we also ran models using Control of Corruption as a proxy for corruption presented in Table 3 . The positive and significant coefficients for Control of Corruption in Models 9 through 12 and for Control of Corruption*Rule of Law in Model 12 further reinforce our conclusions. Using Control of Corruption, a sufficient degree of rule of law is no longer necessary for corruption to affect environmental policies (since Control of Corruption itself is significant). To get a sense of the economic significance of the Control of Corruption coefficient estimate for various levels of Rule of Law, consider first the parameter estimate in Model 12 measured at the Rule of Law sample mean: $7.03-6.49(0.0)=7.03$. However, measured at one standard deviation below the mean the estimate becomes $7.03+$ $6.49(-0.9)=1.19$, and one standard deviation above the mean the estimate becomes $7.03+$ $6.49(0.9)=12.87$. The negative effects of corruption on environmental policies are stronger where rule of law prevails.

Turning to our control variables, GDP and $\mathbf{G D P}^{2}$ are at best only marginally significant. This is somewhat surprising in view of the large literature on the Environmental Kuznets curve, but may reveal the importance of taking rule of law and corruption into account. The OECD country dummy, intended to capture structural differences between countries has the expected sign, but is rarely significant except in Models 9 and 10 where Rule of Law has not been included. Industrialized countries appear to have no greater capacity to implement environmental policy than their developing counterparts once the rule of law, corruption, openness, and income have been controlled. The coefficient for Table Openness is consistently positive and significant across all models, whereas, Percent Nonagricultural Labor is rarely significant, indicating that the worker lobby's net influence does not depend on in its relative size. ${ }^{16}$

\footnotetext{
${ }^{16}$ To control for the proportion of population exposed to industrial pollution (marginal damage), we alternatively used population density and percentage of urban population as controls. Both variables were insignificant and were dropped from the model.
} 
Table 3. Environmental Stringency Equation Regressions, Models 9-12 (Two-Stage Least Squares)

\begin{tabular}{|c|c|c|c|c|}
\hline Variable & Model 9 & Model 10 & Model 11 & Model 12 \\
\hline GDP & $\begin{array}{l}0.001 \\
(1.2)\end{array}$ & $\begin{array}{c}0.001 \\
(2.1)^{* *}\end{array}$ & $\begin{array}{c}-0.002 \\
(1.7)^{* * *}\end{array}$ & $\begin{array}{c}-0.001 \\
(0.9)\end{array}$ \\
\hline $\mathrm{GDP}^{2}$ & $\begin{array}{l}1.00 \mathrm{e}-08 \\
(0.5)\end{array}$ & $\begin{array}{c}-3.77 \\
(1.8)^{* * *}\end{array}$ & $\begin{array}{c}6.19 \\
(2.5)^{* *}\end{array}$ & $\begin{array}{c}1.89 \mathrm{e}-08 \\
(0.7)\end{array}$ \\
\hline Control of corruption $^{+}$ & $\begin{array}{c}10.7 \\
(2.4)^{* *}\end{array}$ & $\begin{array}{c}8.29 \\
(2.2)^{* *}\end{array}$ & $\begin{array}{c}9.22 \\
(2.5)^{* *}\end{array}$ & $\begin{array}{c}7.03 \\
(2.0)^{* *}\end{array}$ \\
\hline (Control of corruption) $^{2+}$ & & $\begin{array}{c}7.09 \\
(3.3)^{*}\end{array}$ & & \\
\hline OECD & $\begin{array}{c}5.73 \\
(2.0)^{* *}\end{array}$ & $\begin{array}{c}7.06 \\
(2.4)^{* *}\end{array}$ & $\begin{array}{l}3.46 \\
(1.3)\end{array}$ & $\begin{array}{l}4.05 \\
(1.5)\end{array}$ \\
\hline $\begin{array}{l}\text { Percent nonagricultural } \\
\text { labor }\end{array}$ & $\begin{array}{c}-0.10 \\
(1.7)^{* * *}\end{array}$ & $\begin{array}{l}-0.07 \\
(1.3)\end{array}$ & $\begin{array}{l}0.002 \\
(0.04)\end{array}$ & $\begin{array}{c}0.005 \\
(0.1)\end{array}$ \\
\hline Openness & $\begin{array}{c}2.78 \\
(2.8)^{*}\end{array}$ & $\begin{array}{c}3.25 \\
(3.4)^{*}\end{array}$ & & $\begin{array}{c}4.03 \\
(3.9)^{*}\end{array}$ \\
\hline Rule of law ${ }^{+}$ & & & $\begin{array}{c}15.0 \\
(3.4)^{*}\end{array}$ & $\begin{array}{c}12.7 \\
(2.9)^{*}\end{array}$ \\
\hline $\begin{array}{l}\text { Control of corruption* } \\
\text { rule of law }\end{array}$ & & & & $\begin{array}{c}6.49 \\
(3.0)^{*}\end{array}$ \\
\hline Constant & $\begin{array}{l}33.9 \\
(6.8)^{*}\end{array}$ & $\begin{array}{c}25.8 \\
(5.0)^{*}\end{array}$ & $\begin{array}{c}41.3 \\
(8.2)^{*}\end{array}$ & $\begin{array}{c}35.7 \\
(8.0)^{*}\end{array}$ \\
\hline $\mathrm{R}^{2}$ & 0.870 & 0.885 & 0.889 & 0.897 \\
\hline Number of observations & 74 & 74 & 74 & 74 \\
\hline $\begin{array}{l}\text { t-statistics in parenthes } \\
* \text { Statistically significa } \\
* * \text { Statistically signific } \\
* * * \text { Statistically signifi } \\
\text { +predicted (fitted) valu }\end{array}$ & $\begin{array}{l}\text { percent le } \\
\text { percent } \\
10 \text { perce }\end{array}$ & & & \\
\hline
\end{tabular}




\section{Conclusion}

This paper develops a theory of how the rule of law affects environmental policy formation. The main insights that emerge are that an increase in the degree of rule of law has two opposing effects on environmental policy. There is a direct positive effect on policy stringency due to an increase in the share of policy decisions taken when the rule of law is followed. However, there is reduction in the policy stringency due to an increase in industry bribery efforts. Moreover, we find that an increase in corruptibility lowers the environmental tax. Finally, the effect of rule of law (corruptibility) is conditional on the degree of corruptibility (rule of law).

We use a data set of 83 countries to assess the extent to which the available data capture the model's insights. The effect of rule of law on environmental policy stringency is positive, in particular, where the degree of corruption is low. On the other hand, corruptibility has a negative effect on environmental policy stringency, in particular, where the degree of rule of law is high.

These findings suggest that secure property rights (a high degree of rule of law) are important for the decision to offer bribes. Reform of the legal system must also address issues related to the corruptibility of policymakers, as the effect on environmental policies may otherwise be diminished. We believe this finding may have more general applicability and merits further study. 


\section{VARIABLE DEFinition AND Data SOURCES}

\begin{tabular}{|c|c|}
\hline Variable & Definition and Source \\
\hline $\begin{array}{l}\text { Environmental } \\
\text { stringency }\end{array}$ & $\begin{array}{l}\text { Captures the extent to which the country has in place institutions and policies that result in effective } \\
\text { responses to environmental problems. It takes values between } 0 \text { and } 100 \text {, where a higher value implies } \\
\text { greater environmental policy stringency. Source: Center for International Earth Science Information } \\
\text { Network (CIESIN), Global Leaders for Tomorrow, and Yale Center for Environmental Law and Policy } \\
\text { (2001), "Environmental Sustainability Index," Columbia University, World Economic Forum, and Yale } \\
\text { University. The data is available at http://www.ciesin.org/indicators/ESI/pilot_esi.html. }\end{array}$ \\
\hline GDP & $\begin{array}{l}\text { GDP Per Capita (PPP) or Purchasing power adjusted GDP is obtained when GDP is converted to } \\
\text { international dollars using purchasing power parity rates. An international dollar thus has the same } \\
\text { purchasing power over GDP as the U.S. dollar in the United States. Source: World Development Indicators } \\
(2000) \text {. }\end{array}$ \\
\hline Corruption & $\begin{array}{l}\text { Corruption Perceptions Index published by Transparency International, describes the level of perceived } \\
\text { corruption in the public sector using a poll of political risk indexes. Original scores range from } 0 \\
\text { (completely corrupt) to } 10 \text { (clean). Average of CPI indexes for years 1997, 1998, and 1999. The index is } \\
\text { inverted in scale by subtracting values from } 10 \text { to make the results more intuitive. Available at: } \\
\text { www.transparency.de/documents/. }\end{array}$ \\
\hline $\begin{array}{l}\text { Control of } \\
\text { corruption }\end{array}$ & $\begin{array}{l}\text { Measures perceptions of corruption in a country, or more precisely, the use of public power for private } \\
\text { gain. The index takes values from }-2.5 \text { to } 2.5 \text {, where a higher value implies greater control over corruption. } \\
\text { Source: Kaufmann and others. (1999a, } 1999 \mathrm{~b}) \text {. }\end{array}$ \\
\hline Rule of law & $\begin{array}{l}\text { A composite index that measure the extent to which agents have confidence in and abide by the rules of } \\
\text { society. Include perceptions of the incidence of both violent and nonviolent crime, effectiveness and } \\
\text { predictability of judiciary, and the enforceability of contracts. It takes a value from }-2.2 \text { (least stringent) to } \\
2.2 \text { (most stringent). Source: Kaufmann and others }(1999 \mathrm{a}, 1999 \mathrm{~b}) \text {. }\end{array}$ \\
\hline Openness & $\begin{array}{l}\text { Index of trade openness developed by the Heritage Foundation and the Wall Street Journal. It takes a value } \\
\text { from } 1 \text { to } 5 \text {. An economy earns a " } 5 \text { " if it has average tariff rate of less than or equal to four percentage } \\
\text { points and/or has very few nontariff barriers, and " } 1 \text { " if the average tariff rate is greater than } 19 \text { Percent } \\
\text { and/or there are very high nontariff barriers that virtually prohibits imports. A greater index number } \\
\text { indicates a greater degree of openness. Source: O'Driscoll and others. (2000). }\end{array}$ \\
\hline $\begin{array}{l}\text { Percent } \\
\text { nonagricultural } \\
\text { labor }\end{array}$ & $\begin{array}{l}\text { Proportion of the total labor force recorded as working in nonagricultural sectors. Source: World } \\
\text { Development Indicators }(2000) \text {. }\end{array}$ \\
\hline OECD & Dummy OECD countries taking a value 1 if a country is OECD member, 0 otherwise. \\
\hline Democracy & $\begin{array}{l}\text { Dummy for countries that have been Democratic in all } 46 \text { years between } 1950 \text { and } 1995 \text {, and } 0 \text { otherwise. } \\
\text { Criteria being 1) the chief executive is elected; 2) at least one legislature is elected; } 3 \text { ) more than one party } \\
\text { contests elections; and 4) at least one turnover of power between parties in last three elections. Source: } \\
\text { Alvarez and others (1996) }\end{array}$ \\
\hline Common law & $\begin{array}{l}\text { Dummy for countries with company law or commercial code based on English common law. Source: La } \\
\text { Porta and others (1997). }\end{array}$ \\
\hline Civil war & $\begin{array}{l}\text { Dummy for countries experiencing civil war. It takes values from } 1 \text { if the country had experienced a civil } \\
\text { war and } 0 \text { otherwise. Source: Knack and Keefer (1995). }\end{array}$ \\
\hline Civic freedom & $\begin{array}{l}\text { Index that indicates the freedom enjoyed by the civil society. Take a value from } 1 \text { (most free) to } 7 \text { (least } \\
\text { free). Source: Gwartney and others (2000), Frasier Institute. }\end{array}$ \\
\hline
\end{tabular}




\section{REFERENCES}

Aidt, T.S., 1998, "Political Internalization of Economic Externalities and Environmental Policy," Journal of Public Economics 69 (1), pp. 1-16.

Alvarez, M., J.A. Cheibub, F. Limongi, and A. Przeworski, 1996, "Classifying Political Regimes," Studies in Comparative International Development 31 (2), pp. 2-36.

Antweiler, W., B.R. Copeland, and M.S. Taylor, 2001, "Is Tree Trade Good for the Environment?" American Economic Review 91 (4), pp. 877-908.

Bardhan, P., 1997, "Corruption and Development: A Review of Issues," Journal of Economic Literature 35 (3), pp. 1320-46.

Barro, Robert J., 1997, Determinants of Economic Growth: A Cross-Country Empirical Study (Cambridge, Massachusetts: MIT Press).

Bernheim, B.D., and M.D. Whinston (1986), "Menu Auctions, Resource Allocation, and Economic Influence," Quarterly Journal of Economics 101, pp. 1-31.

Binmore, K. 1994, Game Theory and The Social Contract, Vol. I: Playing Fair (Cambridge, Massachusetts: MIT Press).

Bohn, H. and R.T. Deacon, 2000, "Ownership Risk, Investment, and the Use of Natural Resources," American Economic Review 90 (3), pp. 526-49.

Buchanan, J., 1975, The Limits of Liberty (Chicago: University of Chicago Press).

Center for International Earth Science Information Network (CIESIN), Global Leaders for Tomorrow, and Yale Center for Environmental Law and Policy (2001), "Environmental Sustainability Index," Columbia University, World Economic Forum, and Yale University. Available at http://www.ciesin.org/indicators/ESV/pilot_esi.html.

Cheung, S., 1963, "Private Property Rights and Sharecropping," Journal of Political Economy 76, pp. 1107-22.

Chichilnisky, G., 1994, "North-South Trade and the Global Environment," American Economic Review 84 (4), pp. 851-94.

Coase, R., 1960, "The Problem of Social Cost," Journal of Law and Economics 3, pp. 1-44.

Conconi, P., 2000, “Green and Producer Lobbies: Enemies or Allies?" mimeo (University of Warwick). 
Damania, R. and P.G. Fredriksson (2000), "On the Formation of Industry Lobby Groups," Journal of Economic Behavior and Organization 41(4): 315-35.

Davidson, R. and J. G. MacKinnon (1993), Estimation and Inference in Econometrics, New York: Oxford University Press.

Deacon, R.T. (1994), "Deforestation and the Rule of Law in a Cross-Section of Countries," Land Economics 70(4), 414-30.

Demsetz, H. (1967), “Towards a Theory of Property Rights," Journal of Political Economy 57, 347-59.

Eliste, P. and P.G. Fredriksson (2001), "Environmental Regulations, Transfers, and Trade: Theory and Evidence," forthcoming, Journal of Environmental Economics and Management.

Fisman, R. and R. Gatti (2000), "Decentralization and Corruption: Evidence Across Countries," forthcoming, Journal of Public Economics.

Grossman, G.M. and E. Helpman (1994), "Protection for Sale," American Economic Review 84(4), 833-50.

Gwartney, J., R. Lawson, and D. Samida (2000), Economic Freedom of the World 2000 Annual Report, The Fraser Institute. Available at www.fraserinstitute.ca/publications/books/econ_free_2000/.

Hausman, J. (1983), "Specification and Estimation of Simultaneous Equations Models," in Z. Griliches and M. Intriligator (eds.), Handbook of Econometrics, Amsterdam: North-Holland.

Hettige, H., M. Mani, and D. Wheeler (2000), "Industrial Pollution In Economic Development: The Environmental Kuznets Curve Revisited," Journal of Development Economics 62(2), 445-76.

Heyes, A. and B. Dijkstra (2001), "Interest Groups and the Demand for Environmental Policy", in T. Tietenberg and H. Folmer, eds., International Yearbook of Environmental and Resource Economics 2001/2002, 2001, Edward Elgar, Cheltenham.

Hobbes, T. (1651), Leviathan, ed. by C.B. Macpherson, London: Penguin Classics, 1986.

Kahn, M.E. and J.G. Matsusaka (1997), "Demand for Environmental Goods: Evidence from Voting Patterns on California Initiatives," Journal of Law and Economics 40, 37-73. 
Kahn, M.E., and J.G. Matsusaka, 1997, "Demand for Environmental Goods: Evidence from Voting Patterns on California Initiatives," Journal of Law and Economics 40, pp. 37-73.

Karp, L., S. Sacheti, and J. Zhao, 2001, "Common Grounds Between Free-Traders and Environmentalists," International Economic Review 42 (3), pp. 617-48.

Kaufmann, D., A. Kraay, and P. Zoido-Lobaton, 1999a, "Aggregating Governance Indicators," Policy Research Working Paper \# 2195 (Washington: World Bank). , 1999b, "Governance Matters," Policy Research Department Working Paper \# 2196 (Washington: World Bank).

Knack, S., and P. Keefer, 1995, "Institutions and Economic Performance: Cross-Country Tests Using Alternative Institutional Measures," Economics and Politics 7 (3), pp. 207-227.

La Porta, R., F. Lopez-de-Silanes, A. Shleifer, and R. Vishny (1999), “The Quality of Government," Journal of Law, Economics, and Organization 15, pp. 222-79. , 1997, “Legal Determinants of External Finance," Journal of Finance 52 (3), pp. 1131-1150.

Locke, J., 1690, Two Treatises of Government (Cambridge: Cambridge University Press) 1963.

López, R., and S. Mitra, 2000, "Corruption, Pollution and the Kuznets Environment Curve," Journal of Environmental Economics and Management 40 (2), pp. 137-50.

North, D.C., 1990, Institutions, Institutional Change and Economic Performance (Cambridge: Cambridge University Press).

O'Driscoll, Jr., G. P., K. R. Holmes, and M. Kirkpatrick, 2000, 2000 Index of Economic Freedom, The Heritage Foundation and The Wall Street Journal. Available at www.heritage.org/index.

Olson, M., 1965, The Logic of Collective Action (Cambridge: Harvard University Press).

Persson, T., and G. Tabellini, 1994, "Is Inequality Harmful for Growth?" American Economic Review 84 (3), pp. 600-21.

Rawls, J., 1972, A Theory of Justice (Oxford: Oxford University Press).

Sachs, J.D., and K. Pistor, eds., 1997, The Rule of Law and Economic Reform in Russia, (Boulder, Colorado: Westview Press). 
Schulze, G., and H. Ursprung, 2001, "The Political Economy of International Trade and the Environment," in International Environmental Economics: A Survey of the Issues, ed. by Günther Schulze and Heinrich Ursprung (Oxford: Oxford University Press).

Shleifer, A., and R.W. Vishny, 1993, “Corruption,” Quarterly Journal of Economics 108 (3), pp. 599-617.

Sugden, R., 1986, The Economics of Rights, Cooperation and Welfare (Oxford: Basil Blackwell).

Svensson, J., 1998, "Investment, Property Rights and Political Instability: Theory and Evidence," European Economic Review 42, pp. 1317-1341.

Transparency International, 1999, available at http://www.transparency.de/documents/.

Treisman, D., 2000, “The Causes of Corruption: A Cross-National Study," Journal of Public Economics 76, pp. 399-47.

White, H., 1980, “A Heteroscedasticity-Consistent Covariance Matrix Estimator and a Direct Test for Heteroscedasticity," Econometrica 48, pp. 817-38.

World Bank, 2000, World Development Indicators (Washington: World Bank).

, 1997, World Development Report (Washington: World Bank).

, 1994, Governance: The World Bank's Experience (Washington: World Bank).

Yu, Z., 2000, "Environmental Protection: A Theory of Direct and Indirect Competition for Political Influence," Centre for Globalisation and Labour Markets Research Paper 2000/3 (University of Nottingham). 